\title{
The rise of China and the time of Africa: Gauging Afro-Sino relations in the light of Confucian philosophy and African ideals
}

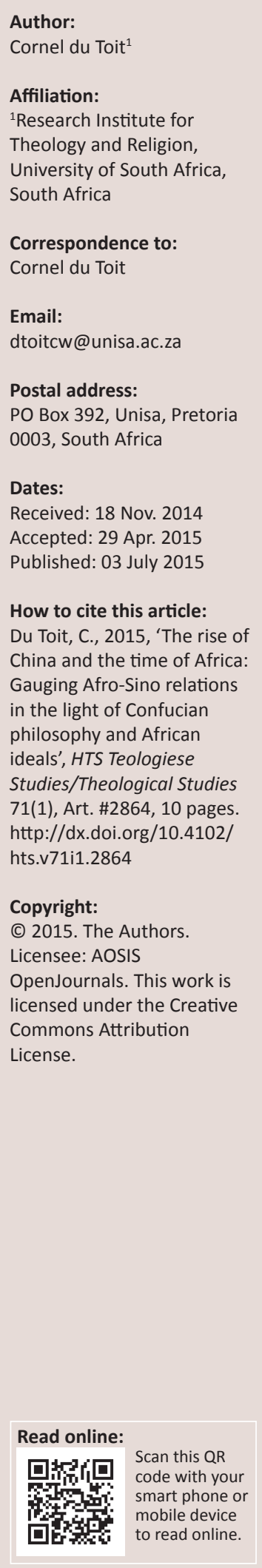

The article focuses on Sino-African relations, with specific reference to South Africa. An outline is provided of recent developments as a roadmap for the unfolding of this relationship. The question of whether China's African interest can be seen as tacit colonisation is discussed. Even if these fears are allayed, the question remains whether the Chinese presence on the continent will make a significant difference to African development. To answer this question, the focus shifts to economic models and the Chinese recipe for economic progress. Confucianism was opposed during the cultural revolution of Mao Zedong, but it now forms the basis for Chinese foreign policy and internal affairs. This is briefly investigated. Some Confucian ideas are related to basic African concepts in an effort to find a common ground in Afro-Chinese relations. The impact of secular Confucianism on African spirituality is discussed.

\section{Introduction}

It is generally recognised that China has come of age as an economic power and that it is spreading its influence. China is the most populous country in the world and it is estimated that it will become the leading economic power by 2018. The 'sleeping giant' from the East has awoken, and it is seemingly making up for lost time.

It is also generally recognised that Africa is on the rise. Events such as the 1994 democratic elections in South Africa and the more recent Arab spring (insofar as it affected African countries such as Tunisia, Egypt and Libya) appear to strengthen this idea. However, Africa needs a great deal of support in facing its many challenges. China is apparently willing to participate in Africa's economic emancipation. China and Africa need each other for different reasons, but a successful relationship could represent a long-awaited turning point for Africa. There are already more than a million Chinese citizens in Africa, and Chinese construction programmes worth billions of dollars have become important factors in the development of most important African metropolises.

It can be argued that the role played by China will be a significant and determinative event in post-colonial Africa. The question is whether Chinese influence will be a 'magical factor' capable of stimulating economic growth and thereby eradicating poverty, disease and illiteracy in Africa. Africa's colonial past has instilled scepticism amongst many Africans as regards foreign influence. The question is: will China's economic and cultural involvement truly benefit the African continent? To answer this question, we must address an underlying question: what are the factors requisite to ensuring a lasting and fruitful relationship between China and its African partner-countries?

As is also generally accepted, many mistakes were made during the West's long involvement in Africa. Western influence, although well entrenched in the continent, is clearly waning, as is evident in diminishing commercial ties. It would certainly be short-sighted of any nation interacting with Africa to ignore past blunders. But effective Chinese involvement in Africa will also require a considerable degree of diplomacy, planning and sound business acumen. Africa is divided into 54 states (all of which are represented at the AU) and has no common language. The continent is plagued by political unrest and war and threatened by a Christian-Muslim divide in the north, whilst it continues to suffer from unstable governments and corruption and widespread illness and disease. It also still lacks effective infrastructure. All of these are amongst the many factors that presently prevent significant development.

Africa has rich resources to offer, but it lacks infrastructure, skills, education, jobs, unity, and specifically peace. In South Africa, for instance, the optimistic NEPAD programme proposed 
by former South African president Thabo Mbeki never got off the ground, mainly because of economic constraints. Meanwhile, China has skills, monetary muscle, human capital, a strong work ethic and the historical experience of conquering poverty and attaining the skills that can be used in a liberal market economy to its advantages. Moreover, it needs resources to maintain and grow its mammoth economy. Chinese involvement may change the African scene and perhaps help to realise some of the continent's much-needed infrastructure. ${ }^{1}$

But more is at stake than economic relations. Economic involvement at such a gigantic scale inevitably involves a range of other factors. Seen from the African perspective, some of these concern African cultural values, Africa's voice in the global arena, environmental concerns in view of increased industrialisation and socio-economic issues. Will Chinese influence make a momentous difference on these levels as well? If Chinese foreign relations are built on cultural and philosophical ideas from its own past, then it is inevitable that an important aspect of China's involvement with other countries will involve a dialogue between its ideas and traditions and those of other cultures.

South Africa is one of the so-called BRICS countries (Brazil, Russia, India, China and South Africa). Its government favours intra-African trade, as well as trade with BRICS countries and the East. Traditionally, Europe, the UK and USA were dominant trade partners, but the People's Republic of China (PRC) has been South Africa's biggest trading partner since 2010. China's investment projects on the African continent topped \$200 billion in 2013.

No one can doubt the seriousness of South Africa's commitment to strengthening ties with China. Simultaneously the ANC is eager to strengthen ties with the other BRICS countries. $^{2}$

The following initiatives between China and South Africa stand out:

- The first visit by a government official to China after the first democratic election in 1994 was the visit of South African Deputy President Phumzile Mlambo-Ngcuka to

1.The fifth Forum on China-Africa..................................................... the following the following planned initiatives with regard to infrastructure development: '4.3 Infrastructure Construction. 4.3.1 The two sides agreed to prioritize infrastructure in China-Africa cooperation and strengthen cooperation in transport, telecommunications, radio and television, water conservancy, electricity, energy and other areas of infrastructure development. 4.3.2 To support Africa in achieving connectivity and integration and developing more integrated infrastructure, China and the African Union will establish a cooperative partnership in the design, inspection, financing and management of projects under the Program for Infrastructure Development in Africa and the Presidential Infrastructure Championing Initiative, strengthen relevant dialogue and exchanges, and provide support for the project planning and feasibility study. 4.3.3 The Chinese government will continue to encourage capable Chinese enterprises and financial institutions to participate in transnational and trans-regional infrastructure construction in Africa and provide preferential loans to support infrastructure building in Africa' (see FOCAC website, http://www.focac.org/eng/).

2.President Zuma met Russian president Putin at the end of August 2014 to discuss the implementation of the Intergovernmental Committee on Trade and Economic Cooperation (ITEC) agreement, trade and investment issues, and preparations for the 12th ITEC Session to be hosted by South Africa during the course of 2014. The situation in Syria, the Israel-Palestine matter, as well as developments in Ukraine were also discussed. The South African government has backed Putin's stance on were also discussed. The
these matters up to now.
China in September 2007. Since 2010, bilateral visits and agreements have proliferated.

- In late March 2010, CPPCC ${ }^{3}$ Chairman Jia Qinglin visited South Africa to sign contracts worth more than $\$ 300$ million.

- In August 2010 President Jacob Zuma led a South African delegation of 17 cabinet members and 300 business people to China, where they signed the Beijing Declaration on the Establishment of a Comprehensive Strategic Partnership between the People's Republic of China and the Republic of South Africa.

- The speaker of the National Assembly of South Africa, Max Sisulu, visited China in October 2010.

- In November 2010, Chinese Vice President Xi Jinping travelled to South Africa to meet with South African Vice President Motlanthe and sign bilateral cooperation agreements in energy, trade statistics, banking regulation and other areas.

- China's top legislator, Wu Bangguo visited South Africa in May 2011 as part of an Africa-Asia tour, which included Namibia and Angola.

- In September 2011 South African Vice President Motlanthe led a trade delegation to Beijing at the invitation of Chinese Vice President Xi. During the visit the China Development Bank and the Development Bank of South Africa signed a \$2.5 billion agreement. The two countries also signed a Memorandum of Understanding on geological exploration and mineral resources.

- On 17 July 2012 President Zuma led a South African delegation that included International Relations Minister Maite Nkoana-Mashabane, Minister in the Presidency Collins Chabane and Trade and Industry Minister Rob Davies, to attend the fifth Forum on China-Africa Co-operation (FOCAC) in Beijing. ${ }^{4}$

- A collaboration agreement between the presidents of China and South Africa was signed in March 2013, when Chinese President Xi Jinping visited South Africa.

- On 04 March 2014, Basic Education Minister, Mrs Angie Motshekga oversaw the signing of an implementation plan between the Ministry of Education in China and the Department of Basic Education in South Africa in Beijing.

- On 10 March 2014, South Africa's Education minister announced the introduction of Mandarin into the school curriculum. An agreement between the two nations focused on five areas of cooperation: curriculum development, maths and science, teacher training, vocational education, and research and development in basic education. On the new partnership, Ministry of Basic Education Spokeswoman Troy Martens said: 'It is very exciting because it takes the relationship between South Africa and China beyond just trade relations and into the mutual development for both of our developing countries.'

- 2014 was declared the year of South Africa in China, on the understanding that the two countries shared excellent international relations and wished to extend

\footnotetext{
3.The Chinese People's Political Consultative Conference (CPPCC), also known as 'The PCC', is a political advisory body in the People's Republic of China.

4.See http://en.wikipedia.org/wiki/China\%E2\%80\%93South_Africa_relations (viewed 10 August 2014)
} 
their relationship beyond trade into areas of mutual development. Education was a priority imperative for both countries and this implementation plan was centred on strengthening education ties at an institutional and policy level.

- Deputy Minister of the Cultural Ministry Ding Wei met with the South African Deputy Minister Ministry of Arts and Culture, Joyce Mabudafhasi, during his state visit to South Africa in August 2014. Ding said the comprehensive strategic partnership between the two countries was facing 'great challenges', but could rely on increasing mutual political trust and deepening pragmatic cooperation. China attached great importance to cultural exchange and cooperation, which it said were an important part of bilateral relations. And China was willing to take the opportunity of the reciprocal cultural year programme to further promote the cultural exchange and cooperation between the two countries as a way of improving bilateral relations.

In addition, Ding Wei and Joy Mabudafhasi signed a Memorandum of Understanding as part of the Reciprocal Cultural Year Programme in 2014 and 2015. ${ }^{5}$

We note, however, that Sino-South-African relations received bad press worldwide when his Holiness the Dalai Lama, who had attended the Parliament of the World's Religions in 1999, was denied a visa after he was asked to attend an international peace conference in South Africa in March 2009. A second visit was also cancelled after he was invited to South Africa for Archbishop Emeritus Desmond Tutu's 80th birthday party on 07 October, 2011. The government's relations with China were the obvious reason the visa was denied. ${ }^{6}$ Following this event the 2014 World Summit of Nobel Peace Laureates in Cape Town was also cancelled because of the large number of laureates that pulled out of the event to protest the government's refusal to grant the Dalai Lama a visa to attend the event.

\section{The impact of Chinese presence in Africa}

Bilateral trade between China and African countries reached $\$ 210$ billion in 2013. An impressive range of cultural and other programmes were launched as part of the programme (see Africa - News and Analysis, 04 May 2014). Large-scale Chinese construction programmes were undertaken and completed very efficiently over short periods of time with predominantly Chinese workers. China has huge investment interests in Angola, the DRC, Nigeria, Kenya, and South Africa, to mention only some of the most significant investment relationships.

\section{See Hao (2014)}

6.A 2013 Pew study found that South Africans had mixed feelings about China. The survey showed that some $46 \%$ of South Africans did not like the spread of Chinese ideas and customs in their country, and $60 \%$ disliked Chinese music, movies and television. If this survey is reliable, the attitudes it reflects are bound to change television. If this survey is reliable, the attitudes it reflects are bound to change
when the impact of Chinese investments becomes visible (see Pew Research when the impact of Chinese investmen
Centre: Religion and Public Life 2013).
Given the powerful entrenched Western interests it faced in Africa, however, Beijing had to offer a unique package of economic, political and security inducements to fast-track its entry to key natural resource-producing regions of the continent. These included: targeted debt relief; participation in peace-keeping operations in countries such as Liberia, DRC and Sudan; cheap loans linked to infrastructure development; political junkets for African leaders to Beijing; support for Africa in global forums such as the United Nations (UN), World Trade Organisation (WTO), International Monetary Fund (IMF) and World Bank; competitive military deals; collaborative projects on 'traditional medicines'; political 'non-interference' in the internal policies of African countries; the promotion of 'south-south' linkages; and the establishment of parallel funding agencies to institutions such as the IMF and World Bank.

A number of initiatives on the cultural level were also launched. In October 2000, the FOCAC was launched in Beijing, to meet every three years. The second FOCAC ministerial conference was held in Addis Ababa, Ethiopia in 2003. FOCAC 5 was held in South Africa (see the FOCAC website for updated initiatives: http://www.focac.org/eng/).

The first conference of the China-Africa Think Tank Forum ${ }^{7}$ was hosted by Zhejiang Normal University in Hangzhou, Zhejiang Province on 27 October, 2011. A high-level platform for China-Africa academic exchanges, the founding of which was approved by the Ministry of Foreign Affairs and Ministry of Commerce of China, the Forum offers a bridge the purpose of which is to link up important ideas of Chinese and African elites. The Foreign Ministry incorporates the China-Africa Think Tank Forum within the framework of the FOCAC as a regular mechanism for civil dialogues between China and Africa, which will be held alternately in China and Africa each year (see FOCAC website at http:/ / www.focac. org/eng/xsjl/t894943.htm).

\section{Post-colonial lessons learnt}

In an interview with the Financial Times (Russell 2013), South Africa's President Zuma warned Western companies to change their old 'colonial' approach to Africa or risk losing out even more to the accelerating competition from China and other developing powers. He said that Western businesses and governments have a 'psychological problem' and are still prone to lecturing Africa. 'Instead of saying: "Let us help you", they come and they say: "Change your economic structure. Don't do this. Do that."'

In his view, this attitude was tainted by more than a hint of colonialism. Zuma warned: 'If you want to treat Africa as a former colony ... then people will go to new partners who are going to treat them differently.' He advised Western

\footnotetext{
7.To put Chinese academic muscle in perspective, refer to the article of Mark Leonard 'China's new intelligentia' (Prospect Magazine, 28 March 2008), in which he relates his first visit, in 2003, to the Chinese Acadne his first visit, in 2003, to the Chinese Academy of Social Sciences (CASS) in Beijing. He was welcomed by Wang Luolin, the academy's vice-president, who told him that his academy had 50 research centres covering 260 disciplines with 4000 full-time researchers - and this was only one of many institutions.
} 
countries and economic interests to resist warning against Africa's relationship with China and to rethink their own investment strategies. Zuma said that Africa was aware of the risks of being' bossed around' by China. 'Africa does not want to be dominated again. China is doing business in a particular way and we think we can see the benefits, but we are very, very careful,' he said, again citing Africa's experience of colonialism. Such a relationship must 'benefit both. And this is what we and China have been agreeing' (Russell 2013).

This was underscored by Premier Li Keqiang before his May 2011 trip to Ethiopia, Nigeria, Angola and Kenya, when he said that he wanted to assure China's African friends in all seriousness that China $\mathrm{w}[$ ould $]$ never pursue a colonialist path like some countries did, or allow colonialism, which belongs to the past, to reappear in Africa'. He stressed that Chinese firms in Africa would adhere to local laws and regulations and protect the interests of local communities. Concerning the threat of a neo-colonialism of Africa, Qianru (2011:153) said: 'China was in a leading position throughout the course of several thousand years of history. It is only the last hundred years or so that China became weak, following powerful invasions. At no time in the past or in the present has China made hegemony over the world the goal of its development.' This statement is of course not necessarily true and could be challenged.

In 2009 China overtook the United States as Africa's biggest trading partner. Xinhua News Agency, China's governmentrun official press agency, said more than 2500 Chinese firms were operating on the continent (Africa - News and Analysis, 04 May 2014). However, Beijing has been accused of holding back the continent's economic development by focusing on the pursuit of raw materials rather than the creation of local jobs and markets (Africa - News and Analysis, 04 May 2014). Human rights groups and Western officials have criticised China's readiness to strike deals with oppressive governments. But South Africa's ruling African National Congress, which admires China's state-led capitalism, has promoted the relationship, arguing South Africa has the necessary laws and diplomatic clout to defend its own interests.

\section{China's success story a recipe for Africa?}

The Chinese economic success story of the last 30 years is based on the country's access to abundant and cheap labour. (This is also valid for India, but that country cannot boast the same successes.) Other factors - such as the emergence of economic globalisation, the digital revolution, lower transaction costs for capitalism and availability of large numbers of well-trained Chinese graduate ${ }^{8}-$ must be taken into account. The Chinese government itself is another important factor: it directly or indirectly commands a large proportion of national assets and income, and is in a unique position to allocate resources. The government is also not subject to the pressures faced by other, democratic 8.Since 1978 over one million Chinese students have received training in foreign countries (especially America). governments and is able to introduce unpopular measures, such as raising taxes. The Chinese government's nearunique ability to command the country's economy may have facilitated China's rapid industrialisation (see Hayat 2011).

Is state control a model for consideration in Africa? It could be argued, for instance, that this is the de facto situation in South Africa, where the ANC-government has a near twothirds parliamentary majority. (Some observers suggest that this boils down to a one-party state.)

Madeleine Bunting, for example, in her review of Dambisa Moyo's 2009 book Dead aid, a critical evaluation of Western aid of $\$ 300$ billion to Africa since 1970, insists that the single important question with regard to African economies is why so many African states fail to function. Moyo, she says, ignores the role of the state in Africa, instead stressing the private sector, free enterprise, and non-interference of the state in business. This is the Western model, which may work within a Western context, but not within an African one. But Bunting asks why Africa has seen so much civil war and so many corrupt dictators. The key elements to many Asian countries' success in the post-Second World War era, she argues, were the role of a strong, interventionist state that nurtured industry and an elite that was invested in its own country. These factors were almost entirely absent in many African countries during the same period; instead, African elites exported capital to Western bank accounts and pursued ruinous policies. In the face of this, Bunting sees Moyo's proposal to phase out Western aid in five years as disastrously irresponsible, arguing that it would lead to the closure of thousands of schools and clinics across Africa and an end to the HIV antiretroviral, malaria and TB programmes, along with emergency food supplies on which millions of lives depend.

We might ask whether a critical and exhaustive list of factors can be identified to explain any particular nation's economic, military, aesthetic, or scientific success. It is part of the modernist legacy that we seek specific 'causes' for an historic event, be it war, economic misfortune or cultural success. But it is also clear that such unilateral causative factors very seldom exist. It might be suggested, for instance, that the kind of religion practiced, or the adoption of specific political philosophies or perhaps the availability of capable political, religious or intellectual leaders can be determinative for a country's success. But the links between economic, military, scientific and religious achievement and specific, pervasive influences - whether ideological, philosophical, religious or the impact of the charismatic leader - remain relative. No direct link between a specific idea and a material success can be definitively demonstrated.

However, there is no point in simply denying any influence of background or cultural factors on countries' economic successes. The challenge is to identify the role of a diverse number of factors that play a significant role in each specific, complex situation under review. 


\section{The use of philosophical 'universals' to regulate international relations: Confucius in Africa}

Confucius, it could be said, is the Socrates of the East. Confucianism dominated China's feudalistic society for thousands of years before the founding of the PRC in 1949. It is remarkable, taking into account that Confucius lived 2500 years ago, that his thinking continues to influence the lives and thinking of millions of people today.

According to Chai (1961:36), the Chinese are 'essentially Confucian in their outlook and mentality; and except for the Buddhist and Taoist trends in the arts and letters, Chinese culture and Confucianism are almost synonymous, if not completely so.' Confucius, and his students Lao Tzŭ (circa 6th century BC), Mencius (372-289 BCE), and Chang Tzŭ (399-295 BCE) provided a philosophical basis for Chinese culture. Lao $\operatorname{Tzu}^{9}$ was the founder of Taoism ${ }^{10}$, Mencius popularised Confucian thought and Chang Tzŭ was a romantic mystic (Chai 1961:69). Chinese culture may be built on the pillars of Confucianism, Taoism and Buddhism, but these traditions are so old and so diffused over so many population groups that it is difficult to decide which of their aspects are still relevant today. To what extent can ancient wisdom be normative in a global world in which human rights and democratic accountabilities are widely accepted ${ }^{11}$

The Western analogy may be informative. We know that Western thought has its basis in classical Greek culture. To pinpoint direct causal lines of thought is however difficult. Chai (1961:xxiii) refers to early Greek migration which eventually covered the limits of the world as it was then known. The Greek migrations were linked to curiosity about the universe and man's role in it and boosted the interaction between philosophy and science as expressed in the work of Pythagoras, Plato, Aristotle and the like.

Developments in China were radically different, probably largely because of geographical factors. China lies in the centre of the great land mass of Eastern Asia and it is likely that no need was felt for outside exploration. 'It is not surprising to find the world of man more important to the ancient Chinese than the world of nature. Their thought was focused on social and political problems instead of scientific ones, with the result that, where the Greeks were scientists

9.Although probably a legendary figure, he is reckoned a contemporary of Confucius.

10.It needs to be pointed out that Taoism is critical of Confucianism, and therefore not merely a continuation of it.

11.The aim of Confucianist humanism is to protect the ruler, not the ordinary people. Though it claims to be concerned for the people and to pay attention to their needs, what it is really interested in is in using them to serve the ruler's own interests. Confucianism divides people into two groups: mental labourers and manual Confucianism divides people into two groups: mental labourers and manual labourers. 'Those who do mental labour rule and those who do manual labour are ruled. The Confucianist ideas of patriotism, world commonwealth and harmonious relationships have exerted great influence on modern human rights thought. In the past, they encouraged the Chinese people to safeguard their state independence and national sovereignty, to fight for freedom and human rights. At present, the are still of theoretical and practical importance in dealing with various relationships, in promoting world human rights dialogue and cooperation, as well as pushing
forward Chinese and international human rights development' (see Chunde 2014). and philosophers, the Chinese were political theoreticians and philosophers' (Chai 1961).

In Africa, too, where exploratory migrations similar to the Greek example were absent, the emphasis fell on community life. It was the people that determined the fate of the people, the community that determined the place of the individual and it was in the communal realm that the ideas that shaped the fate of the community were born. This is captured by the African idea of ubuntu. Because of this specifically African history, it may be that a natural affinity between African and Chinese philosophical ideas can be identified.

Mencius usually converted political issues to moral ones. This emphasis makes him such an important thinker in a context were present-day international relations are based on Chinese philosophy. Xu (2011:178) stresses the importance of morality in this context: 'The influence of morality and values cannot be discounted in international relations or in a state's foreign policy. Hence, Mencius's international political philosophy with its moral idealism still has something to contribute to the realisation of China's foreign policy and to international relations theory' (Xu 2011).

A common thread in traditional Chinese thought, and in Confucianism, is the idea that all human beings are born and brought up in the context of a family, and that the world is nothing but an enlarged family (Chun 2012:xi). Filiality, that is, 'the relation or attitude of a child to a parent ${ }^{\prime 12}$, is related to this and the paradigm for all inter-personal relations. This is not foreign to the African idea of $u b u n t u$, and fits in with the idea of the extended family as important pillar of social life.

As the prominent intellectual Yan Xuetong maintains, 'any creation in China's international relations theory must be on the basis of our ancient, traditional culture and thought. On the basis of traditional cultural thought we should mirror the experience of foreign theories and in that way we can more quickly create a worthwhile theory' (Xin 2011:239-240). Taking the difference in worldviews into account, as well as differences in the political, culture and social worlds of ancient Chinese sages and present-day leaders, one cannot but suspect that lessons taken from the past will be those that in one way or another suit what leaders wish to achieve today.

The same hermeneutical questions confront all present-day religions that are based on ancient texts. But hermeneutical and other important preconditions are conceded by Qianru (2011:154-155). He mentions that research in pre-Qin interstate philosophy has attempted to formulate abstract principles linked to a specific historical background and then to use these principles to interpret texts by the pre-Qin masters. Analytical and other methods were used to find logical connections in these texts, which were then compared with Western international political theory. The results were then applied to real politics (Qianru 2011:155).

12.Merriam-webster dictionary (n.d.). 
Because of the difficulty in verifying the truthfulness of historical events, the emphasis fell on the thought of the pre-Qin masters. Qianru acknowledges that 'no reading of history is able to free itself entirely from the subjective hermeneutical perspective of the research' (Qianru:156). It is therefore meaningful to identify the factors singled out by leading Chinese thinkers as the foundations of present-day Chinese culture. We select a few pivotal ideas.

\section{Heaven, earth and the human}

It is difficult to determine whether Confucianism is a philosophy or a religion or a kind of spiritual morality. From a Western philosophical point of view, Confucianism is strictly speaking not a philosophy, although it does involve elements of wisdom; it might perhaps be identified as an ethical system, with the emphasis on harmonious relations between ruler and ruled, patriarch and family, and other members of the family. But Confucianism is not a religion either, and should not be identified with Buddhism or Daoism.

The question is now whether the Chinese success story can be ascribed to the ethos of Confucianism. In his 1915 publication The religion of China: Confucianism and Taoism, Gellner indicated that Weber sets out to evaluate (perceived) differences in the economic performance of China and the West. Weber asked whether, at any point in their history, non-European civilisational traditions had within them the religious and cultural resources to give rise to a 'capitalist spirit', as had occurred in the forms of Protestantism that emerged from the Reformation in Europe and later in North America. His studies of China, South Asia, and the Islamic world were a counterpart to his famous 'Protestant ethic' thesis in the European context (Gellner 2011:49).

Chinese culture, he argues, did not develop capitalism to the same extent as the West. He ascribes this to a number of factors, including Chinese urban development, Chinese patrimonialism and officialdom and the influence of Chinese moral philosophies and religion (Confucianism, Taoism). Chinese cities never attained political autonomy and in fact sometimes enjoyed fewer rights than villages. The lack of city development was partially due to strengths of kinship ties, which stemmed from religious beliefs in which ancestral spirits were central, and consequently served to maintain strong ties to the villages in which one's ancestors lived. Chinese guilds also competed against each other for the favour of the emperor, and did not cooperate to fight for more rights (see Gellner 2011: 48-62).

The key condition lacking in China, according to Weber, was a necessary 'spiritual' factor, some equivalent of the Protestant ethic capable of inducing entrepreneurs to live austerely, endlessly reinvesting their profits in further capitalistic activity. Instead the Chinese chose to focus their efforts in turning themselves (and their progeny) into gentleman (Gellner 2011:50). Chinese civilisation had no religious prophecy, nor any powerful priestly class. The emperor was the high priest of the state religion and the supreme ruler. As Weber understood it, Confucianism tolerated the simultaneous existence of many popular cults and made no effort to organise them as part of a religious doctrine, whilst nonetheless curtailing the political ambitions of the priests and officials of these cults. Instead it emphasised the need to continually adjust to a changing world. This was in sharp contrast with medieval Europe, where the Church was often able to superimpose its will on secular rulers, and where rulers, nobility and the common folk shared the same religion.

As Peter Berger (2012:2) puts it: 'Thus there has been the view of Confucianism as nothing but a secular, perhaps even a secularising morality. There has also been the view that Confucianism, despite the overwhelmingly secular content of its teachings, is based on a worldview that is ultimately religious - indeed the view that Confucianism is a religion.' But in his view the values promoted by Confucianism are secular and are not bound to religious beliefs or practices. It can be regarded as a secular morality because its teachings are almost exclusively concerned with behaviour. Its central values concern altruism or human-mindedness (ren), ritual and etiquette ( $(i)$ and filial piety (xiao). These moral principles are applied to the so-called 'five bonds' - between ruler and subject, father and son, husband and wife, older and younger brother and friend and friend. The first four 'bonds' are explicitly hierarchical; the fifth deals with relations between equals, but the assumption is that they are equal in status within the overall hierarchy (Berger 2012:2-3).

Chai (1961:36-37) sees the notion of ren as the hermeneutical key to Confucianism. It stresses good relations. It teaches one how to be a good ruler, citizen, parent, child or neighbour. 'If modern civilization is to survive, human relations, instead of being based on domination, must be founded on the principle of ren' (Chai 1961:38). Ren is built on filial piety. Filial piety is feasibly the cornerstone of Chinese culture, pre-dating Confucius by some time. It can be seen as the generic source of all virtue, serves as the basis of public morality, maintains the spiritual continuity between the living and the dead, and links together the creative powers of Heaven, Earth and Human order. It concerns authority and responsibility and represents the Confucian principle of reciprocity or mutual response (De Bary 1999:325). What Heaven has endowed is called nature. To 'follow nature' is called 'the Way'. Cultivating the Way is called instruction (see De Bary 1999:334).

According to Berger (2012:3-4), the Confucian belief in tian, usually translated as 'heaven', is unambiguously religious. He sees it as a cosmic and supernatural order that transcends the empirical world, over which it presides and with which it interacts. It thus serves as the religious foundation for all the secular virtues propagated by Confucian teachings. It is most clearly expressed in the notion of the 'Mandate of Heaven'. We will focus on this in more detail.

According to Chun (2012:x), in Chinese religious thought the integration of Heaven and Human involves all physical beings. Civilians were seen as heavenly citizens (tianmin), 
emperors as heavenly sons (tianzi), and every human being was seen as endowed with heavenly conscience (tianliang). Humans are born with heavenly benevolence, and Confucianism values human life greatly. Confucian social morals became the civilian norm and basis of the official societal ideology. The chief moral principles were filial piety, loyalty, and righteousness to family, country, and the world under heaven.

Chun (2012:36) identifies the 'five meanings of heaven' as sky, nature and natural law, the idea of $\operatorname{God}^{13}$, moral principles and fate as destined by the heavens (see also De Bary 1999:335). The Mandate of Heaven grants the emperor the right to rule and is applicable to only one emperor at a time. It implies that the emperor is competent and virtuous. It also implies that no specific dynasty is guaranteed to rule for ever. The Mandate of Heaven is given to a just ruler who is called Son of Heaven. Heaven will not mandate a despotic ruler, and despotism will result in his fall. Once fallen, a ruler has lost the Mandate of Heaven. The fall of the emperor as the result of a successful rebellion is a sign that he had lost the Mandate of Heaven and the rebel leader has gained it.

The idea was first applied to the rule of the kings of the Zhou Dynasty (1046-256 BCE) to support their claims to be just rulers, and to legitimate their overthrow of the earlier Shang dynasty. Similarly, the Qin Dynasty ended in 206 BCE after successful uprisings led by the peasant rebel leader Liu Bang, who founded the Han Dynasty. The same happened in 1644 when the Ming Dynasty (1368-1644) lost the Mandate and was overthrown by Li Zicheng's rebel forces. Li Zicheng's rule was in turn ousted by the Manchus, who founded the Qing Dynasty (1644-1911), China's last imperial dynasty.

\section{All under heaven and possessing all under heaven}

Xunzi (313-238 BCE) was a philosopher who lived during the Warring States Period. The basis of Xunzi's view of state power was the idea of 'all under heaven'. He identified three kinds of international powers, namely humane authority, hegemony, and tyranny (De Bary \& Bloom 1999:161-183; Yan 2011:70). Like Mencius, Xunzi believed that it was the humaneness and rightness of the true king that justified his unassailable authority and an ability to compel the allegiance of others (De Bary \& Bloom 1999:166).

'All under heaven' means world leadership and not simply heading a state. World leadership or 'possessing all under heaven' cannot be seized, but is given (Yan 2011:86). Mencius considered human nature to be good; on this basis he defended the Confucian ideal and developed an account of the self-cultivation process. Xunzi challenged this view and articulated the alternative view, that human nature is bad. Yan (2011:87-88) has argued that Xunzi's idea that morality was the foundation for attaining leadership under heaven by

13. Heaven was believed to be the origin of all beings in the universe. The Shang Dynasty developed a hierarchy of gods for the religion. The highest being of heaven (god) was followed by the natural world, and then human ancestors (see Chun 2012:42). using the example of The Vatican occupying a small space but exerting its authority right over the world. For Xunzi, only a sage could possess humane authority: 'The sage is someone who possesses the Way, is perfect all round and is the standard for judging the authority under heaven' (Yan 2011:87). In contrast, hegemony is regarded as 'a condition of interstate domination in which the ruler's moral level falls short of that required for humane authority ...' (Yan 2011: 88). As might be expected, tyranny is ranked lower than hegemony because it relies on military force and stratagems to invade the territory of other states (Yan 2011:89).

By contrast, Xunzi viewed human nature as evil. In his view, people strove only for personal gain. This led to competition and, inevitably, to violent conflict. This is a stance based on political realism, which 'believes that politics, like society in general, is governed by objective laws, which have their roots in human nature ... Human nature, in which the laws of politics have their roots, has not changed since the classic philosophies of China, India, and Greece endeavoured to discover [them]' (Yan 2011:92).

\section{Yan and the philosophical basis of Chinese foreign policy}

Born December 07, 1952 in Tianjin, China, Chan is dean of the Institute of Modern International Relations at Tsinghua University and chief editor of The Chinese Journal of International Politics (Oxford University Press). He experienced the Cultural Revolution first-hand as part of the construction corps, and persevered through much suffering (see Xin 2011:230-231). He received his PhD in political science from the University of California, Berkeley in 1992. In 2008 he was named as one of world's top 100 public intellectuals by the American journal Foreign Policy. His book, Analysis of China's National Interests won the 1998 China Book Prize, and his Practical methods of International Studies was authorised as a text book by the Chinese Education Ministry in 2006. His views closely mirror those of Chinese leaders (see Xin 2011:229-237, 239).

When he returned to China after completing his Berkeley studies, he noted that no one studied the motives behind Chinese foreign policies, or how they worked in practice, or the relation between the country's domestic policies and foreign policies (Xin 2011:238). These were pivotal issues that he set out to study.

Yan's vision for Chinese foreign relations is frank. In his view, China's national interest is the starting point of all its foreign policy (Xin 2011:238). At the same time, though, he argues that China's international relations theory must be built on the basis of the country's ancient, traditional culture and thought (Xin 2011:239-240). This is worked out in detail in Chapter 2 of his book (Yan 2011:70-106). He also identifies a problem currently faced by China: its lack of meaningful academic critical discussion, which he sees as a result of the political set-up in China. International relations 
cannot be severed from politics, and politics cannot be freely discussed (Yan 2011:240). He laments that foreign relations policy did not allow more freedom in the development of foreign relations theory, which is only currently beginning to develop (Yan 2011:246).

A question that arises here is: How can present-day foreign relations theory be built upon a philosophy as well as a series of 'historical' events that occurred long ago? For it appears that present-day official thinking is based on the pre-Qin period and its interstate political philosophy, which have been selected as the main source and reference for understanding present-day foreign policy (Qianru 2011:147).

The Zhou dynasty (c.1046-256 BC) followed the Shang dynasty and preceded the Qin dynasty. Although the Zhou dynasty lasted longer than any other dynasty in Chinese history, the dynasty's actual political and military control of China lasted only until $771 \mathrm{BCE}$, a period known as the Western Zhou. In about 900 BCE, the feudal empire of Zhou began to decay, as the princes of individual feudal states grew stronger and weaker states were eliminated by warfare (see Chai 1961:xxiv; Qianru 2011:148). During the spring and autumn periods (8th to 3rd century BCE) several large princely states enjoyed sovereignty and control over territory - indispensable features of any modern state.

\section{Confucius institutes in South Africa}

By the end of 2013, 440 Confucius Institutes and 646 Confucius Classrooms had been established worldwide. There are now 25 Confucian institutes across Africa, usually linked to universities. Confucian Institutes in Southern Africa countries are situated at the universities of Zimbabwe, Botswana, and Antananarivo in Madagascar. There are four Confucius Institutes in South Africa, situated at Rhodes University ${ }^{14}$, Tshwane University of Technology in Pretoria, Stellenbosch University ${ }^{15}$ and the University of Cape Town. ${ }^{16}$

The Confucian institutes seem to be the desired instrument to promote cultural links between the two countries. The main aim of these institutes is to teach Mandarin (simplified traditional Chinese) - a similar objective to that of the Alliance Francaise, for example. Confucian thought may surface in this context, but is not treated as a subject in its own right. Aside from teaching Mandarin, as the institute at the University of Cape Town is doing, these institutes teach credit-bearing courses through university schools of language and literature and organise cultural events. Free Chinese classes are offered to University of Cape Town students through an agreement between the relevant institution and the Chinese Hanban, the Chinese Language International Office (see Makoni 2010).

14.The Institute at Rhodes was launched in August 2008 with Marius Vermaak as director.

15.The Confucius Institute of Stellenbosch University (CISU) is currently managed by co-directors Professor Zuo Xu Xie of Hanban and Mr Hennie Kotze of the Postgraduate and International Office of Stellenbosch University.

16.Professor Wu Qianlong is the deputy director of the Confucius Institute at the University of Cape Town. He foresees that courses in Mandarin and Chinese studies will eventually become available to the public.

\section{Buddhism in South Africa}

The Chinese do not consider Buddhism to be a significant part of Confucianism. In the South African context, Buddhism has traditionally been more important than Confucianism. Buddhism was first introduced to South Africa on a very small scale by Indian indentured labourers who were drafted into the sugar industry around Durban in Natal after 1860 (Krüger 1991:32). Around 1917 the Overport Sakya Buddhist Society was formed under the inspiration of Rajaram Dass, the son of an Indian Buddhist revivalist. This organisation later became the Natal Buddhist Association. Buddhism, however, never had a black following in South Africa and Buddhist activities are limited to the initiatives of some individuals in Natal and the Western Cape (see Krüger 1991:32-33).

Various Buddhist groups grew up in the major cities from the 1970s, and there has been a proliferation of distinct Buddhist traditions since the mid-1980s. ${ }^{17}$ These include Theravada, Zen, Nichiren and Tibetan schools. The Fo Guang Shan Buddhist order has erected the Nan Hua Temple, the largest Buddhist temple and monastery in Africa, in the town of Bronkhorstspruit near Pretoria.

The following persons have contributed significantly to the establishment of South African Buddhism: Rob Nairn (Buddhist teacher, author and populariser); Leela Verity (founder and director of Sat Chit Anand); Heila and Rodney Downey (students of Zen Master Seung Sahn); Jennifer Woodhull (student of Pema Chödrön); Kelsang Mila (resident teacher at the Vajrapani Centre in Johannesburg) and Professors Michel Clasquin and Jacobus Krüger (both from the University of South Africa). Mahayana Buddhism has received quite some attention in South Africa, possibly because of some similarities between its views and those of Christianity. The bodhisattva ideal advocates the dedication of one's life to the well-being of the world, for example (see Keown 2013:62ff.; Krüger 1991; 1995).

A PEW study estimated that in 2010 between $0.2 \%$ and $0.3 \%$ of the South African population, or between 100000 and 150000 people were adherents of the Buddhist tradition. This may include adherents of Taoism and Chinese folk religion. However, the number of active practitioners of Buddhism might have been quite small (see Pew Research Centre: Religion and Public Life 2012).

\footnotetext{
17.For Buddhist centres and groups in South Africa see Dharma centres in South Africa, http://buddhactivity.org/action.htm?-Response=buddhacountry.htm\&ccountry= South Africa. The following centres are operative. Western Cape: Diamond Way Buddhist Centre, Cape Town; Kagyu Samye Dzong - Tibetan Buddhist Meditation Centre, Kenilworth, Cape Town; Sat Chit Anand Buddhist Centre, Plettenberg Bay, Home of contemporary Zen in South Africa; Tushita Kadampa Buddhist Centre, Cape Town; Hout Bay Theravada Buddhist Centre; Shambala Training Centre, Cape Town; Tibetan Meditation Centre and Tea House, Simons Town; Bodhi Khaya Retreat Centre, Gansbaai (Overberg region); Vipassana Association of South Africa, Worcester KwaZulu-Natal: Dharmagiri Buddhist Hermitage; Buddhist Retreat Centre Ixopo; Maitreya Kadampa Buddhist Centre Hillcrest/Durban Retreat Centre, Ixopo; Maitreya Kadampa Burban; Mahasiddha Kadampa Buddhist Centre, Durban; Nyingmapa Tradition Buddhis Centre (Dzogchen teaching), Amanzimtoti. Gauteng: Diamond Way Buddhis Centre, Johannesburg; Nan Hua Monastery; Johannesburg Meditation Centr (JMC); Lam Rim B Centre, Johannesburg; Shantikula Buddhist Centre, Johannesburg. Other centre countrywide: Kagyu Lineage of Tibetan Buddhism in South Africa; Soka Gakkai International - South Africa and Emoyeni Retreat Centre, North-West.
} 
Buddhist traditions are represented in South Africa in many forms. Temples, centres and groups are common in the metropolitan areas and the country is thought to include the largest Buddhist community in Africa. The very impressive Buddhist temple, the Nan Hua Temple Complex, is situated at Bronkhorstspruit, which is near Johannesburg and $60 \mathrm{~km}$ from Pretoria.

Krüger (1995:14) mentions that Buddhism is exotic to South Africa, and even feared. This attitude may be applicable to a small minority of Christians, but it remains true that Buddhism is not a religion in the normal sense of the word and is generally not experienced as a threat. In 'secularised' form it is practiced in the forms of Yoga, mindful meditation and reiki healing, amongst other practices. These are not essentially religious, but adhered to out of health or wellbeing concerns, and sometimes as a matter of fashion. Ideas pertaining to reincarnation, karma, chakras and various practices having their origins in Buddhism and Hinduism are not uncommon (Singleton 2014:152).

\section{Resumé: Confucianism and African religions}

Chai (1961:38) criticises Confucianism as being too humanistic, too focused on an ideal life and too little interested in the need for progress and change. 'Thus the old systems are to be preserved but not reformed; the ideas of the past to be venerated but not criticised. The result has been an overbalanced conservatism that the modern Chinese are most emphatic in condemning' (Chai 1961). Chinese foreign policy could have focused on pure presentday pragmatic concerns without reverting to the country's cultural legacy and traditions. But it appears that its respect for tradition and age-old ideas has tremendous appeal and offers adherents hope for the future. The extent to which ageold philosophical ideals will affect present-day realpolitik where politics seeks to accommodate human needs remains to be seen.

Reading this discussion in light of the African principles discussed, it would appear that there are sufficient mutual points of contact. The challenge would be to translate these to everyday pragmatic action.

The economic presence and impact of China in Africa cannot be doubted. This influence will become stronger as more investment and mutual cooperation deals are made and begin to take effect. China has no colonial interests in Africa, nor would they be needed as long as economic pacts ensure a steady flow of raw material to China.

The interesting question is why China spends so much time and effort on establishing Confucianism on the continent. The country's emphasis is very evidently not on Taoism or Buddhism but on Confucianism, as can be seen from the number of institutes that have sprung up on the continent. Confucianism is not a religion, but neither is it comparable to classical ideologies. Should it be valued as a kind of secular spirituality? Even this cannot be stated with certainty. The question is how it will affect Christianity, Islam and African indigenous spiritualities. We know that Confucianism is reviving in China and spreading in countries all over the world. New interactions between the revived Confucianism, Islam, and Christianity are inevitable.

Books have been published recently that focus on Confucianism as a spiritual tradition. The work of Fenggang Yang and Joseph B Tamney is a good example. It is a collection of articles by prominent intellectuals in China and the West, many of them leading experts in multiple disciplines.

That the 2500 year-old Confucian tradition is reviving cannot be doubted. It boasts a spiritual richness, practical wisdom and guidance regarding topics such as self-cultivation, education, family relationships, social commitment and political engagement. This is not unique to Confucianism. What is unique is that for the first time in history, Africa will be confronted with these ideas and the culture that supports them. This poses fascinating challenges for established African religions.

Sino-Afro history is still in the process of being constructed. Chinese initiatives to introduce Confucianism to Africa may have a fruitful outcome - with the proviso that a frank dialogue between Confucian and African ideas will be necessary. It can be expected that, as Chinese economic activity becomes more conspicuous on the continent, cultural interaction will follow. If both parties put their cards on the table, and if the interactions are mutually beneficial, a fertile relationship can be expected for decades to come.

\section{Acknowledgements Competing interests}

The author declares that he has no financial or personal relationships which may have inappropriately influenced him in writing this article.

\section{References}

Berger, P., 2012, 'Is Confucianism a religion?', in The American Interest, 15 February, viewed June 2013, from http://www.the-american-interest.com/2012/02/15/ is-confucianism-a-religion/

Bunting, M., 2009, 'The road to ruin', The Guardian, viewed from http://www. theguardian.com/books/2009/feb/14/aid-africa-dambisa-moyo

Chai, S., 1961, The story of Chinese philosophy, Greenwood Press, Westport, CT.

Chun, S., 2012, Major aspects of Chinese religion and philosophy. Dao of inner saint and outer king, Springer Verlag, Berlin/Heidelberg.

'China writes off African economic grievances with China as "growing pains"', in African Analysis, 04 May 2014, viewed June 2013, from http://africajournalismtheworld. com/tag/china-africa

Chunde, G., 2014, Confucian human rights ideas and their influence on modern human rights thought, China Society for Human Rights Studies, viewed 13 June 2013, from http://www.humanrights.cn/zt/magazine/200402004827111009.htm

De Bary, T., 1999, 'Heaven, earth and the human in the classic of Filiality (Xiaojing)', in T. de Bary \& I. Bloom (eds.), Sources of Chinese tradition, pp. 325-329, Sage, New Delhi, Singapore, Washington, DC.

De Bary, T. \& Bloom, I. (eds.), 1999, Sources of Chinese tradition, Vol. I, From Earliest Times to 1600, Columbia University Press, New York, NY.

FOCAC website: http://www.focac.org/eng/ 
Gellner, D.N., 2011, 'The uses of Max Weber: Legitimation and amnesia in Buddhology, South Asian history, and anthropological practice theory', in P. Clarke (ed.), The Oxford handbook of the sociology of religion, pp. 48-62, Oxford University Press, Oxford. http://dx.doi.org/10.1093/oxfordhb/9780199588961.013.0003

Hao, W., 2014, 'China and South Africa co-signed the memorandum of understanding of the reciprocal cultural', in China Culture, viewed June 2013, from http://www1. chinaculture.org/info/2014-08/21/content_558702.htm

Hayat, U., 2011, 'What explains China's economic growth, and is it sustainable?', in Enterprising investor, viewed 12 August 2014, from http://blogs.cfainstitute.org/ investor/2011/12/06/what-explains-china $\%$ E2\%80\%99s-economic-growth-andis-it-sustainable

Keown, D., 2013, Buddhism, Oxford University Press, Oxford. http://dx.doi. org/10.1093/actrade/9780199663835.001.0001

Krüger, J.S., 1991, Buddhism from the Buddha to Asoka, University of South Africa, Pretoria.

Krüger, J.S., 1995, Along edges: Religion in South Africa - Bushman, Christian, Buddhist, National Book Printers, Pretoria.

Leonard, M., 2008, 'China's new intelligentia', Prospect Magazine, viewed from http:// www. prospectmagazine.co.uk/features/chinese-intelligentsia-intellectuals-thinktanks

Makoni, M., 2010, 'AFRICA: Confucius institutes grow Chinese', University World News, viewed 05 September 2010, from http://www.universityworldnews.com/ article.php?story $=201009050726299731$

Merriam-webster dictionary, n.d., 'filiality', viewed 14 April 2015, from http://www. merriam-webster.com/dictionary/filiality

Moyo, D., 2009, Dead aid: Why aid makes things worse and how there is another way for Africa, Farrar, Straus and Giroux, New York, NY.
Pew Research Centre: Religion and Public Life, 2012, Global religious landscape Religious composition by country, viewed 18 December 2012, from http://www. pewforum.org/files/2012/12/globalReligion-tables.pdf

Pew Research Centre: Religion and Public Life, 2013, Chapter 3. Attitudes toward China, viewed 18 November 2013, from http://www.pewglobal.org/2013/07/18/chapter3-attitudes-toward-china/

Qianru, Y., 2011, 'An examination of the research theory of pre-Qin interstate political philosophy', in X. Yan (ed.), Ancient Chinese thought, modern Chinese power, pp. 147-160, Princeton University Press, Princeton and Oxford.

Russel, A., 2013, 'Zuma warns west's “colonial” corporates', in Financial Times, viewed 10 August 2014, from http://www.ft.com/cms/s/0/7824cc28-83ed-11e2-b70000144feabdc0.html\#ixzz3BNwFNNZn

Singleton, A., 2014, Religion, culture, society. A global approach, Sage, Los Angeles, CA, London, New Delhi, Singapore, Washington, DC.

Weber, M., 1965, The Protestant ethic and the spirit of capitalism, Unwin University Books, London.

Xin, L., 2011, 'A realist scholar clinging to scientific prediction', in X. Yan (ed.), Ancient Chinese thought, modern Chinese power, pp. 229-251, Princeton University Press, Princeton, NJ/Oxford.

$\mathrm{Xu}, \mathrm{J.}$., 2011. 'The two poles of Confucianism: A comparison of the interstate political philosophies of Mencius and Xunzi', in X. Yan, (ed.), Ancient Chinese thought, modern Chinese power, pp. 161-180, Princeton University Press, Princeton, $\mathrm{NJ} /$ Oxford.

Yan, X., 2011, 'Xunzi's interstate political philosophy and its message for today', in X. Yan (ed.), Ancient Chinese thought, modern Chinese power, pp. 70-106, Princeton Press Princeton, NJ/Oxford. 